九州大学学術情報リポジトリ

Kyushu University Institutional Repository

\title{
Requirement of Redlip Mullet for Dietary Phosphorus
}

\section{El-Zibdeh, Mohammad}

Fishery Research Laboratory, Faculty of Agriculture, Kyushu University

Yoshimatsu, Takao

Fishery Research Laboratory, Faculty of Agriculture, Kyushu University

Matsui, Sei ichi

Fishery Research Laboratory, Faculty of Agriculture, Kyushu University

Furuichi, Masayuki

Fishery Research Laboratory, Faculty of Agriculture, Kyushu University

他

https://doi.org/10.5109/24100

出版情報：九州大学大学院農学研究院紀要. 40 (1/2)，pp. 135-145，1995-12. Kyushu University バージョン：

権利関係 : 


\title{
Requirement of Redlip Mullet for Dietary Phosphorus*
}

\section{Mohammad El-Zibdeh, Takao Yoshimatsu, Seiichi Matsui, Masayuki Furuichi, Chikara Kitajima and Ryusuke Azuma ${ }^{\dagger}$}

\author{
Fishery Research Laboratory, Faculty of Agriculture, \\ Kyushu University, Fukuoka 81 1-33, Japan \\ (Received July 26,1995)
}

\begin{abstract}
The requirement of dietary phosphorus was investigated in two age groups of redlip mullet, Lizahematochiela. Fish with initial mean weights $3.8 \mathrm{~g}$ (zero year-old) and $26.5 \mathrm{~g}$ (one yearold) were fed on purified diets containing varying dietary levels of phosphorus (0.3 to $1.1 \%)$. Results from two studies indicated that the available phosphorus requirement of redlip mullet is approximately $0.7 \%$. In both experiments weight gain together with feed efficiency were maximal in fish fed diets containing $0.6-0.7 \%$ dietary phosphorus, but further elevation above this level did not result in a better growth. In a zero year-old fish, it was found that the decrease in the dietary $\mathrm{P}$ level resulted in the increase in the lipid, and the decrease in $\mathrm{Ca}, \mathrm{P}$ and crude ash contents of vertebrae. However, no such effect was observed for the one year-old fish. In all groups both serum and bone $\mathrm{Ca} / \mathrm{P}$ ratio performed values of 3: 1 and $1: 1$ in zero and one yearold redlip mullet, respectively, suggesting a predominancy of $\mathrm{Ca}$ content in body tissues at early stages. Hence. the change in balance between $\mathrm{Ca}$ and $\mathrm{P}$ is an age dependent.
\end{abstract}

\section{INTRODUCTION}

Phosphorus is an essential element for animals for the formation of bone, maintenance of entire cellular membranes of the soft tissues and for lipid and carbohydrate metabolism.

The required levels of phosphorus are the highest of all the inorganic ions required for most fishes. The dietary requirement, was found to range from $0.5-0.9 \%$ available phosphorus for many freshwater and marine fishes.

Studies by several workers (Andrews et al., 1973; Sakamoto and Yone, 1978; Ogino et al., 1979; Ogino and Takeda, 1976, 1978 and Yone and Toshima, 1979) have revealed that phosphorus is essential for the health and well-being of the animal organisms. The most significant symptoms of phosphorus deficiency in fish include: 1) reduced growth, 2) low feed efficiency and 3) bone deformity.

The primary purpose of the present investigation was to obtain information on the dietary phosphorus requirement of the redlip mullet L. haematochiela, since the nutrition of minerals of redlip mullet is still inadequate despite its importance in fisheries and aquaculture ( $\mathrm{Wu}, 1984)$. This study is to examine the efficiency of dietary phosphorus on growth, food conversion, hematology and chemical composition of fish soft tissues and bones in two age classes of the redlip mullet. The experimental work was carried out under ambient temperature and laboratory conditions at the Fishery Research Laboratory of Kyushu University, Japan.

\footnotetext{
* Contribution from Fish. Res. Lab., Kyushu University, No. 207.

${ }^{+}$Hihon Nosan Kogyo Co. Ltd., Minato-Mirai, Nishi-Ku, Yokohama, Japan
} 


\section{MATERIALS AND METHODS}

\section{Experimental design}

Two feeding studies were conducted with zero (Exp. I) and one year-old (Exp. II) redlip mullet fingerlings. Experiments were conducted in a $150-\mathrm{L}$ rectangular flowthrough aquaria with flow rates of approximately $1.2-1.8 \mathrm{l} / \mathrm{min}$. Rearing sea water temperature was ranged between $21-24.5$ and $22.5-29.5^{\circ} \mathrm{C}$ in experiments I and II, respectively. Prior to initiation of the experiments, the fish underwent a 2-3 weeks conditioning period during which they fed on a purified diet containing adequate amounts of $\mathrm{P}(0.7 \% \mathrm{mg})$ and acclimatized to indoor-laboratory conditions.

\section{Diets}

Basal diet (Table 1) was formulated from purified ingredients to contain 55 and $50 \%$ crude protein in experiment I and II, respectively. Dietary ingredients were commercially obtained: vitamin free casein as protein source, dextrin and $\alpha$-starch as the source of digestible carbohydrate, pollack liver oil as lipid source and the vitamin mixture Halver's $(1957)+\alpha$-cellulose. Digestible energy in the experimental diets was maintained at about $350 \mathrm{Kcal} / 100 \mathrm{~g}$ diet.

Sodium phosphate monobasic $\left(\mathrm{NaH}_{2} \mathrm{PO}_{+} \cdot 2 \mathrm{H}_{2} \mathrm{O}\right)$ was substituted in place of $\alpha$ cellulose in order to obtain 5 levels $(0-0.9 \% \mathrm{P})$ of supplemental phosphorus (Table 2). To each diet the mineral mixture was supplemented at $8 \%$ level.

Since casein contains certain amount of inorganic P $(5.9 \mathrm{mg} / \mathrm{g})$. The levels of total phosphorus in test diets were measured colorimetrically using the molybdenum blue method.

Table 1. Percent composition of the basal diets fed to redlip mullet in'experiments I (zero'year-old) and II (one year-old).

\begin{tabular}{lcc}
\hline Ingredients & & II \\
\hline Casein*1 & 55 & 45 \\
Dextrin & 10 & 15 \\
a -Starch & 5 & 10 \\
Pollack liver oil & 10 & 10 \\
Vitamin mixture*2 & 3 & 3 \\
Mineral mixture*3 & 8 & 8 \\
CMC*4 & 0 & 5 \\
Guar gum & 3 & 0 \\
$\alpha$-Cellulose & 6 & 4 \\
\hline Total & 100 & 100 \\
\hline DE (Kcal/100g diet) *5 & 353 & 348 \\
*1 Vitamin free milk casein. & \\
*2 Halver's vitamin mixture (1957)+ a-Cellulose. \\
*3 See Table 2. \\
*4arboxymethylcellulose. \\
*5 Digestible energy (assumed from the values for carp (Ogino \\
$\begin{array}{l}\text { et al., 1976): 4kcal/g protein, 8kcal/g lipid and 3.5kcal/g } \\
\text { digestible carbohydrate. }\end{array}$
\end{tabular}


Table 2. Mineral mixture supplemented to test diets in experiment I and II.

\begin{tabular}{|c|c|c|c|c|c|}
\hline Diet No. & 1 & 2 & 3 & 4 & 5 \\
\hline $\begin{array}{l}\text { Supplemental P } \\
\text { (mg/100g diet) }\end{array}$ & 0 & 200 & 400 & 600 & 900 \\
\hline $\mathrm{KCl} \quad(\mathrm{g})$ & 26.15 & 26.15 & 26.15 & 26.15 & 26.15 \\
\hline $\mathrm{MgSO}_{4} \cdot 7 \mathrm{H}_{2} \mathrm{O}$ & 27.25 & 27.25 & 27.25 & 27.25 & 27.25 \\
\hline $\mathrm{NaH}_{3} \mathrm{PO}_{2} \cdot 2 \mathrm{H}_{2} \mathrm{O}$ & 0.00 & 50.40 & 100.80 & 151.00 & 226.70 \\
\hline Fe-citrate & 5.91 & 5.91 & 5.91 & 5.91 & 5.91 \\
\hline $\begin{array}{l}\text { Ca-la ctate } \\
\text { T.E. *2 (mg) }\end{array}$ & 98.05 & 98.05 & 98.05 & 98.05 & 98.05 \\
\hline $\mathrm{AlCl}_{3} \cdot 6 \mathrm{H}, \mathrm{O}$ & 35.60 & 35.60 & 35.60 & 35.60 & 35.60 \\
\hline $\mathrm{ZnSO}_{1} .7 \mathrm{H}_{\mathrm{O}} \mathrm{O}$ & 710.00 & 710.00 & 710.00 & 710.00 & 710.00 \\
\hline $\mathrm{MnSO}_{1} \cdot 4-6 \mathrm{H}_{3} \mathrm{O}$ & 159.20 & 159.20 & 159.20 & 159.20 & 159.20 \\
\hline $\mathrm{CuCl}$ & 22.00 & 22.00 & 22.00 & 22.00 & 22.00 \\
\hline $\mathrm{KI}$ & 34.00 & 34.00 & 34.00 & 34.00 & 34.00 \\
\hline $\mathrm{CoCl}_{2} .6 \mathrm{H}, \mathrm{O}$ & 208.80 & 208.80 & 208.80 & 208.80 & 208.80 \\
\hline$\alpha$-Collulose (g) & 241.15 & 190.75 & 140.35 & 90.15 & 14.45 \\
\hline Total (g) & 400 & 40 & 400 & 400 & 400 \\
\hline
\end{tabular}

Levels of absolute P (mg/100 g diet) in the experimental diets

\begin{tabular}{|l|cc|c|cc|}
\hline Diet No. & 1 & 2 & 3 & 4 & 5 \\
Experiment I*' & 366 & 539 & 681 & 864 & 1106 \\
\hline Experiment II*' & 307 & 559 & 709 & 901 & 1036 \\
\hline
\end{tabular}

*1 One gram casein contains $5.9 \mathrm{mg}$ P.

*2 Trace elements.

\section{Fish and Feeding}

Redlip mullet with average body weights $3.8 \pm 0.1$ and $27.0 \pm 0.8 \mathrm{~g}$ were sorted into five groups of 30 and 20 fish in experiment I and II, respectively. Each group was placed in an individual tank and fed 2-3 times/day to satiation with the desired experimental diet adjusted previously to be appropriate according to the size of fish mouth. Feeding period was extended to 14 weeks for zero year-old fish and 12 weeks for the one year-old fish.

\section{Measurements and analytical methods}

Body weight of individual fish from each experimental group was measured at biweekly intervals. At the end of feeding trial, weight-gain, feed efficiency, daily growth rate, daily feed intake, condition factor and hepatosomatic index in the two experiments were measured. Blood samples were taken by cardiac puncture from 10 fish randomly selected in each group of the two experiments. Hemoglobin content $(\mathrm{Hb})$, hematocrit value $(\mathrm{Ht})$ and serum total protein were determined by cyanmethemoglobin method, microhematocrit method and ATAGO hand refractometer, respectively. Inorganic $\mathrm{P}, \mathrm{Ca}$, triglyceride and total cholesterol in pooled samples of blood serum were quantified by RaBA (Rapid Blood Analyzer-Super) and Unikit (Chugai Pharmaceutical Co.). A composite samples of vertebrae and/or liver were combined from all fish of each experimental group from the two experiments and subjected to proximate composition 
analysis (moisture, crude protein, crude lipid and crude ash). Inorganic $\mathrm{P}, \mathrm{Ca}, \mathrm{Mg}, \mathrm{Mn}$, $\mathrm{Cu}, \mathrm{Fe}$ and $\mathrm{Zn}$ contents of vertebrae and/or liver were determined by a Perkin-Elmer (3300) Atomic Absorption Spectrophotometer.

\section{Statistical analysis}

Student's t-test was employed for significance determination between means in the case of growth, hepatosomatic index and Condition factor. Hematological data were subjected to analysis of variance and treatment significance was determined by the Fisher's LSD test.

\section{RESULTS AND DISCUSSION}

Experiment I. Dietary phosphorus at level $0.37 \%$ had substantial effect on growth rate (Fig. 1). The response of zero year-old fingerlings of redlip mullet to increasing levels of phosphorus are presented in Table 3. There were no apparent increase in average weight gain, feed efficiency, daily growth rate, daily feed intake and hepatosomatic index as the level of available phosphorus above $0.54 \%$. Condition factor at the two dietary phosphorus levels $(0.90$ and $0.11 \%)$ have shown significantly lower values $(P<0.05)$.

Effects of dietary graded levels of phosphorus on hematological characteristics and serum $\mathrm{P}$ and $\mathrm{Ca}$ are summarized in Table 4 . No significant difference $(P>0.05)$ was

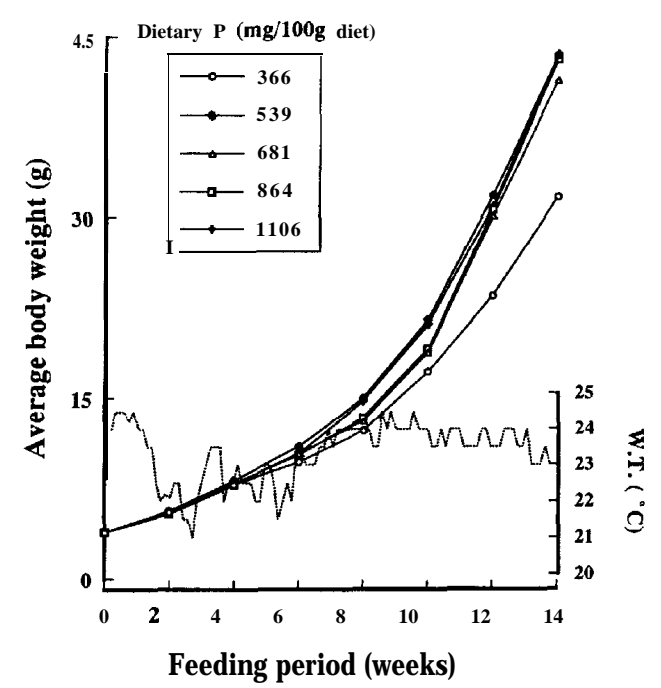

Fig. 1. Growth of zero year old-redlip mullet fed on purified test diets with graded levels of dietary phosphorus for 14 weeks. Right panel shows the change in rearing water temperature (W.T.). 
Table 3. Effect of dietary phosphorus levels on growth and efficiency of feed utilization of zero year-old redlip mullet.

\begin{tabular}{|c|c|c|c|c|c|}
\hline $\begin{array}{c}\text { Dietary P } \\
\text { (mg/100g diet) }\end{array}$ & 366 & 539 & 681 & 864 & 1106 \\
\hline $\begin{array}{c}\text { Average body weight (g) } \\
\text { at start }\end{array}$ & $3.8 \pm 0.1$ & $3.8 \pm 0.1$ & $3.8 \pm 0.1$ & $3.8 \pm 0.1$ & $3.7 \pm 0.1$ \\
\hline after 14 weeks & $31.6 \pm 1.8^{\mathrm{a}}$ & $43.6 \pm 2.1^{b}$ & $41.5 \pm 2.4^{\mathrm{b}}$ & $43.2 \pm 2.8^{b}$ & $43.7 \pm 2.6^{\mathrm{b}}$ \\
\hline Average weight gain $(\%)$ & 732 & 1046 & 991 & 1034 & 1054 \\
\hline Feed efficiency $(\%)$ & 67 & 88 & 91 & 90 & 90 \\
\hline Daily growth rate & 1.7 & 1.9 & 1.9 & 1.9 & 1.9 \\
\hline Daily feed intake & 2.06 & 2.13 & 2.07 & 2.08 & 2.08 \\
\hline Hepatosomatic index $* 1$ & $1.01 \pm 0.04^{\mathrm{a}}$ & $1.18 \pm 0.06^{\mathrm{a}}$ & $1.17 \pm 0.03^{\mathrm{a}}$ & $1.13 \pm 0.09^{\mathrm{a}}$ & $1.08 \pm 0.07^{\mathrm{a}}$ \\
\hline Condition factor $* 2$ & $1.31 \pm 0.02^{\mathrm{a}}$ & $1.30 \pm 0.02^{\mathrm{a}}$ & $1.28 \pm 0.02^{\mathrm{a}}$ & $1.22 \pm 0.02^{\mathrm{b}}$ & $1.25 \pm 0.02^{\mathrm{b}}$ \\
\hline
\end{tabular}

Values within the same row which bears different letters are significantly different, $\mathrm{P}<0.05$ (Fisher's LSD test and Student's t-test).

*1 Liver weight $(\mathrm{g}) \times 100 /$ body weigth $(\mathrm{g})$.

*2 Body weight $(\mathrm{g}) \times 10^{*} /$ [body length $\left.(\mathrm{cm})\right]$ '.

Table 4. Effects of dietary phosphorus levels on the hematological characteristics and chemical components of the blood serum of zero year-old redip mullet.

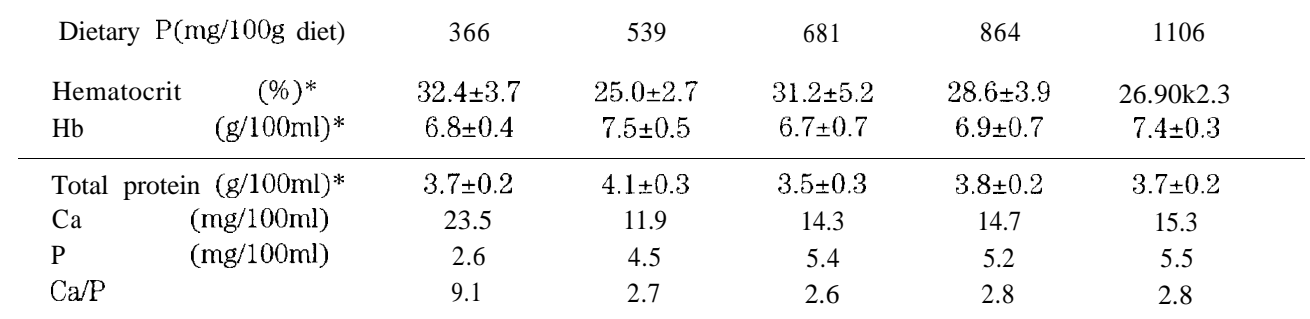

* Not significantly different, $P<0.05$ (ANOVA, Fisher;s LSD test).

detected in the values of $\mathrm{Ht}, \mathrm{Hb}$ and serum total protein among all fish groups. However, at $0.37 \%$ dietary phosphorus level, serum $\mathrm{Ca}$ content was highest to approximately two times more $(23.5 \mathrm{mg} / 100 \mathrm{ml})$ and $\mathrm{P}$ content was lowest to $1 / 2$ times less $(2.6 \mathrm{mg} / 100 \mathrm{ml})$ than their contents in the other groups (average 14.1 and $5.2 \mathrm{mg} / 100 \mathrm{ml}$ of $\mathrm{Ca}$ and $\mathrm{P}$ respectively), resulted in a sharp increase of $\mathrm{Ca} / \mathrm{P}$ ratio. Similar trend was reported by Wilson et al. (1982), when the serum Ca of channel catfish elevated 1.5 times at the lowest level of dietary phosphorus $(0.03 \%)$ compared to other levels. They presumed that it could be attributed to a greater mobilization of bone calcium at this level. The elevation of lipid content with the decrease of dietary P levels was recognized in vertebrae (Fig. 2). Sakamoto and Yone (1978) reported similar influence on the lipid content of red sea bream and suggested that the decrease in dietary phosphorus levels may promote the absorption of dietary lipid or inhibit the glycogenesis in the fish resulting in the acceleration of protein and carbohydrates transformation into lipid.

Mark decrease of ash, $\mathrm{Ca}$ and $\mathrm{P}$ contents of vertebrae was observed at 0.37 and 0.54 $\%$ dietary phosphorus in experiment I. Brittle bone formation was found to be as a result 

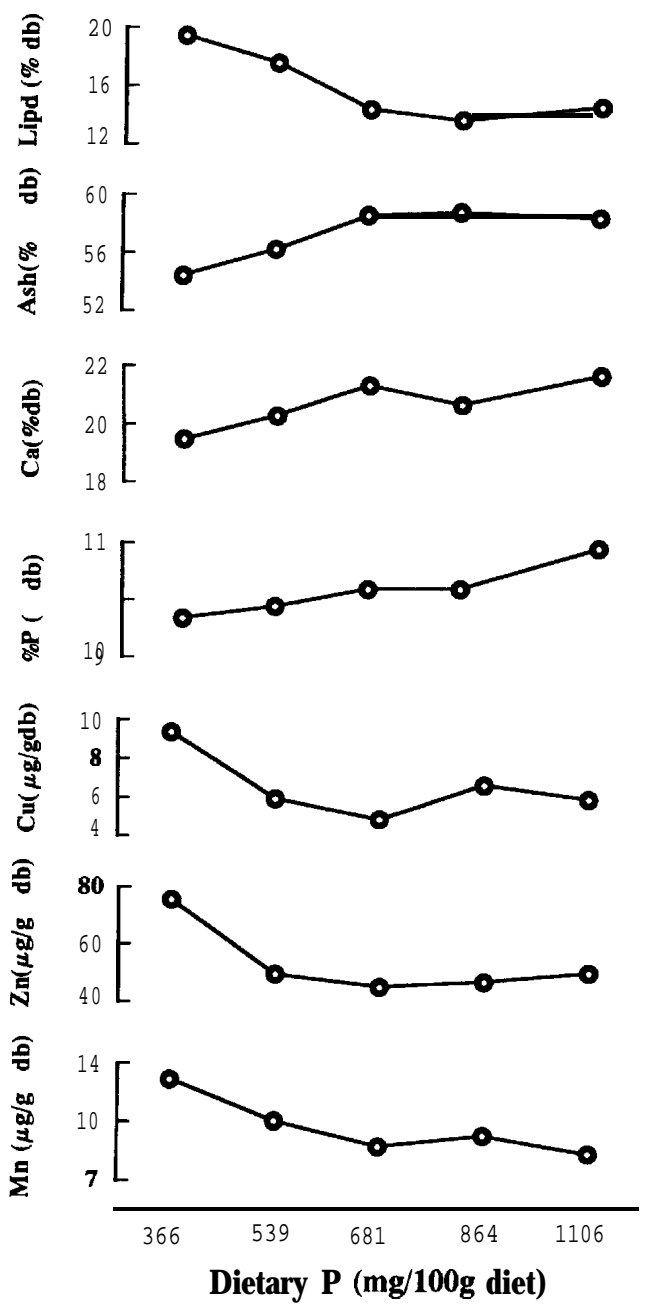

Fig. 2. Effect of dietary phosphorus on lipid, ash and mineral contents of the vertebrae of zero year-old redlip mullet. $\mathrm{db}$; values in dry weight basis.

of reduced contents in mineral composition of vertebrae (Sakamoto and Yone 1978; Ogino and Takeda, 1976).

Experiment II. The effect of graded levels of dietary phosphorus on growth and feed efficiency utilization in one year-old fish are presented in Fig. 3 and Table 5, respectively. A dietary level of about $0.7 \%$ available phosphorus was found to be adequate based on the results of growth, average weight gain and feed efficiency. No significant difference in $\mathrm{Ht}$ values was detected among all groups. However, $\mathrm{Hb}$ was 


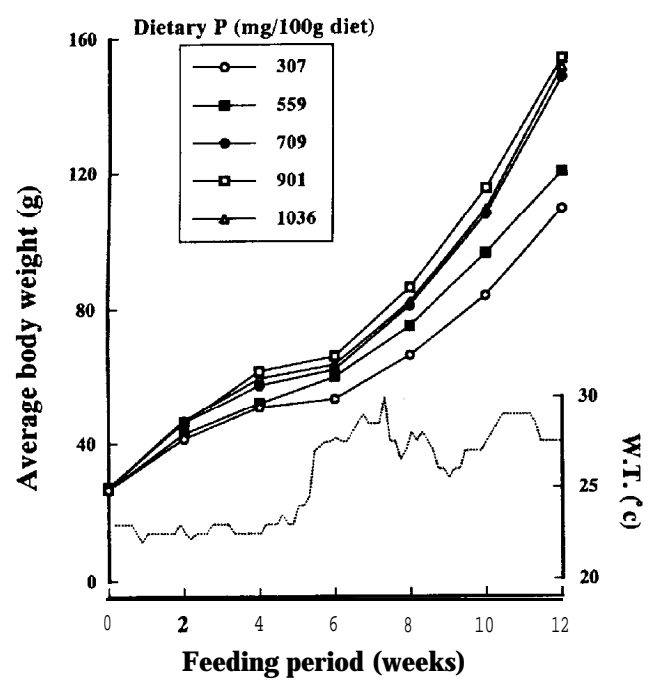

Fig. 3. Growth of one year-old redlip mullet fed on purified test diets with graded levels of dietary phosphorus for 12 weeks. Right panel shows the change in rearing water temperature (W.T.).

Table 5. Effect of dietary phosphorus levels on growth and efficiency of feed utilization of one year-old redlip mullet.

\begin{tabular}{|c|c|c|c|c|c|}
\hline $\begin{array}{c}\text { Dietary P } \\
\text { (mg/100g diet) }\end{array}$ & 307 & 559 & 709 & 901 & 1036 \\
\hline $\begin{array}{c}\text { Average body weight (g) } \\
\text { at start }\end{array}$ & $26.6 \pm 0.8$ & $26.7 \pm 0.9$ & $27.1 \pm 0.9$ & $27.3 \pm 0.8$ & $27.2 \pm 0.8$ \\
\hline after 12 weeks & $109.4 \pm 28.5^{b}$ & $120.4 \pm 30.0^{\mathrm{b}}$ & $148.5 \pm 29.4^{\mathrm{a}}$ & $154.1 \pm 28.9^{a}$ & $151.5 \pm 27.1^{\mathrm{a}}$ \\
\hline Average weight gain $(\%)$ & 564 & 533 & 607 & 597 & 613 \\
\hline Feed efficiency & 47 & 55 & 60 & 61 & 60 \\
\hline Daily growth rate $(\%)$ & 1.45 & 1.52 & 1.54 & 1.66 & 1.59 \\
\hline Daily feed intake (\%) & 3.05 & 2.70 & 2.92 & 2.41 & 2.79 \\
\hline Hepatosomatic index $* 1$ & $1.16 \pm 0.24^{\mathrm{a}}$ & $1.08 \pm 0.19^{\mathrm{a}}$ & $1.10 \pm 0.25^{\mathrm{a}}$ & $1.01 \pm 0.20^{\mathrm{a}}$ & $1.16 \pm 0.20^{\mathrm{a}}$ \\
\hline Condition factor $* 2$ & $1.62 \pm 0.13^{\mathrm{a}}$ & $1.53 \pm 0.09^{\mathrm{b}}$ & $1.53 \pm 0.10^{\mathrm{b}}$ & $1.46 \pm 0.08^{\mathrm{b}}$ & $1.51 \pm 0.11^{\mathrm{b}}$ \\
\hline
\end{tabular}

Values within the same row which bears different letters are significantly different, $\mathrm{P}<0.05$ (Fisher's

LSD test and Student's t-test).

*1 Liver weight $(\mathrm{g}) \times 100 /$ body weigth $(\mathrm{g})$.

*2 Body weight $(\mathrm{g}) \times 10^{3} /$ [body length $\left.(\mathrm{cm})\right]^{*}$.

significantly higher and triglyceride exhibited maximal value in fish groups fed 0.56 and $0.70 \%$ dietary phosphorus compared to other groups (Table 6). Serum Ca and serum P were not influenced by the different dietary phosphorus levels. Therefore, $\mathrm{Ca} / \mathrm{P}$ ratio was maintained at about 0.9 which is markedly lower than the values of $\mathrm{Ca} / \mathrm{P}$ ratio in experiment I. In zero year-old fish serum $\mathrm{Ca}$ and serum $\mathrm{P}$ were markedly influenced by 
Table 6. Effects of dietary phosphorus levels on the hematological characteristics and mineral contents of the blood serum of one year-old redip mullet.

\begin{tabular}{lcccccc}
\hline \multicolumn{2}{l}{ Dietary P(mg/100g diet) } & 307 & 559 & 709 & 901 & 1039 \\
\hline Hematocrit & $(\%)$ & $27.8 \pm 4.9^{\mathrm{a}}$ & $24.5 \pm 2.5^{\mathrm{a}}$ & $24.9 \pm 2.4^{\mathrm{a}}$ & $25.2 \pm 2.7^{\mathrm{a}}$ & $24.4 \pm 3.8^{\mathrm{a}}$ \\
$\mathrm{Hb}$ & $(\mathrm{g} / 100 \mathrm{ml})$ & $8.8 \pm 102^{\mathrm{a}}$ & $9.8 \pm 0.7^{\mathrm{b}}$ & $10.2 \pm 0.8^{\mathrm{b}}$ & $9.0 \pm 2.1^{\mathrm{a}}$ & $8.9 \pm 0.7^{\mathrm{a}}$ \\
\hline \multicolumn{2}{l}{ Total protein $(\mathrm{g} / 100 \mathrm{ml})$} & $4.6 \pm 0.4^{\mathrm{a}}$ & $4.6 \pm 0.4^{\mathrm{a}}$ & $4.6 \pm 0.3^{\mathrm{a}}$ & $4.4 \pm 0.5^{\mathrm{a}}$ & $4.3 \pm 0.4^{\mathrm{a}}$ \\
Triglyceride & $(\mathrm{mg} / 100 \mathrm{ml})$ & 125 & 184 & 202 & 163 & 208 \\
Total Cholesterol $(\mathrm{mg} / 100 \mathrm{ml})$ & 75 & 313 & 335 & 215 & 164 \\
$\mathrm{Ca}$ & $(\mathrm{mg} / 100 \mathrm{ml})$ & 12.6 & 12.2 & 12.2 & 12.8 & 11.2 \\
$\mathrm{P}$ & $(\mathrm{mg} / 100 \mathrm{ml})$ & 14.7 & 13.3 & 13.1 & 13.4 & 12.7 \\
$\mathrm{Ca} / \mathrm{P}$ & & 0.9 & 0.9 & 0.9 & 1.0 & 0.9 \\
\hline
\end{tabular}

Values within the same row which bears different letters are significantly different, $\mathrm{P}<0.05$ (ANOVA, Fisher's LSD test).

the level $0.37 \%$ dietary phosphorus, while no effect was observed at $0.31 \%$ in one year-old fish. Similar results were also observed in the vertebrae of the one year-old fish when the balance between these two minerals remain almost stable at about 1:1 in all groups (Fig. 4), whereas in the zero year-old fish groups about 3:1 suggesting that the change in value of $\mathrm{Ca} / \mathrm{P}$ ratio in fish soft and hard tissues of redlip mullet is a function of development.

The contents of $\mathrm{Mn}, \mathrm{Cu}$ and $\mathrm{Zn}$ in vertebrae were higher in the group fed on the lowest level of dietary phosphorus (0.3\%) than other groups in experiment I (Fig.2), indicating that phosphorus deficiency may retards the utilization of these minerals in redlip mullet leading to its accumulation in bone. However, this case was not clearly noticed in experiment II (Fig. 4). Therefore, if the contents of $\mathrm{Ca}$ and $\mathrm{P}$ have to be considered in the role of maximum bone mineralization in the present two experiments, since both are essential for the synthesis of calcium phosphate matrix in bone (Nose and Arai, 1979; Lall, 1991), our results demonstrates that redlip mullet required more dietary phosphorus for normal bone mineralization than for maximum weight gain. This agree with that reported in a recent study of rainbow trout by Ketola and Richmond (1994).

Results of the proximate composition of liver showed incomparable values of crude ash and crude lipid detected between groups of the two experiments but almost no change was observed among fish groups of the same experiment (Fig.5). It is unclear why such differences in results from the two experiments has appeared, unless it probably indicates that phosphorus requirement for advanced stages of redlip mullet was partially satisfied by the surrounding water (Tempeletone et al., 1963; Ichikawa et al., 1961) compared to small fish which characterized by rapid growth than larger fish. Hence, adequate amounts of dietary $\mathrm{P}$ are needed for the calcification of bone.

Based on the growth and the efficiency of feed utilization results from the two experiments, it is plausible to suggest a value of $0.6-0.7 \%$ apparent available phosphorus in formulating redlip mullet feed. The dietary phosphorus requirement determined in the present study is higher than requirement value of $0.4 \%$ reported for channel catfish (Wilson et $a l ., 1982$ ), while similar to the requirement values 6-8\% available phosphorus for carp, rainbow trout and red sea bream (Ogino and Takeda 1976, 1978; Sakamoto and Yone 1978). 

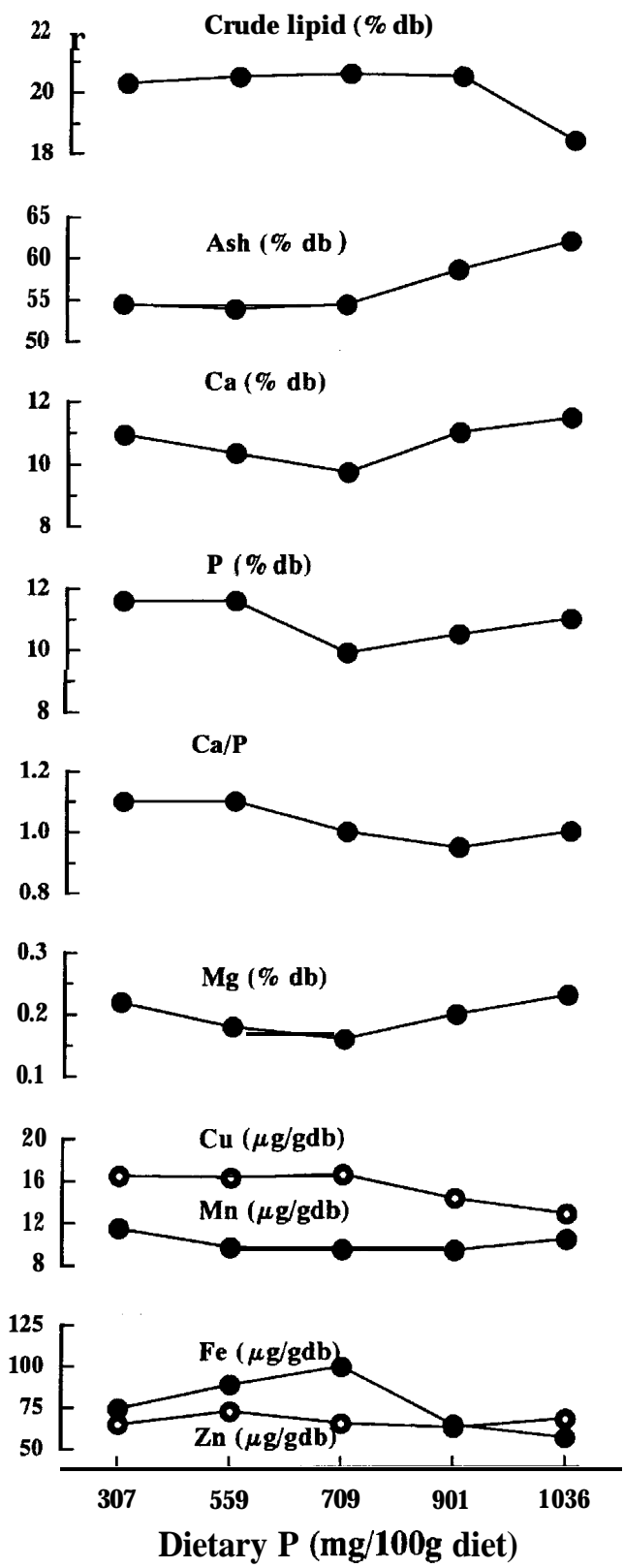

Fig. 4. Effects of dietary phosphorus on lipid, Ash and mineral contents of the vertebrae of one year-old redlip mullet. $\mathrm{db}$; values in dry weight basis. 

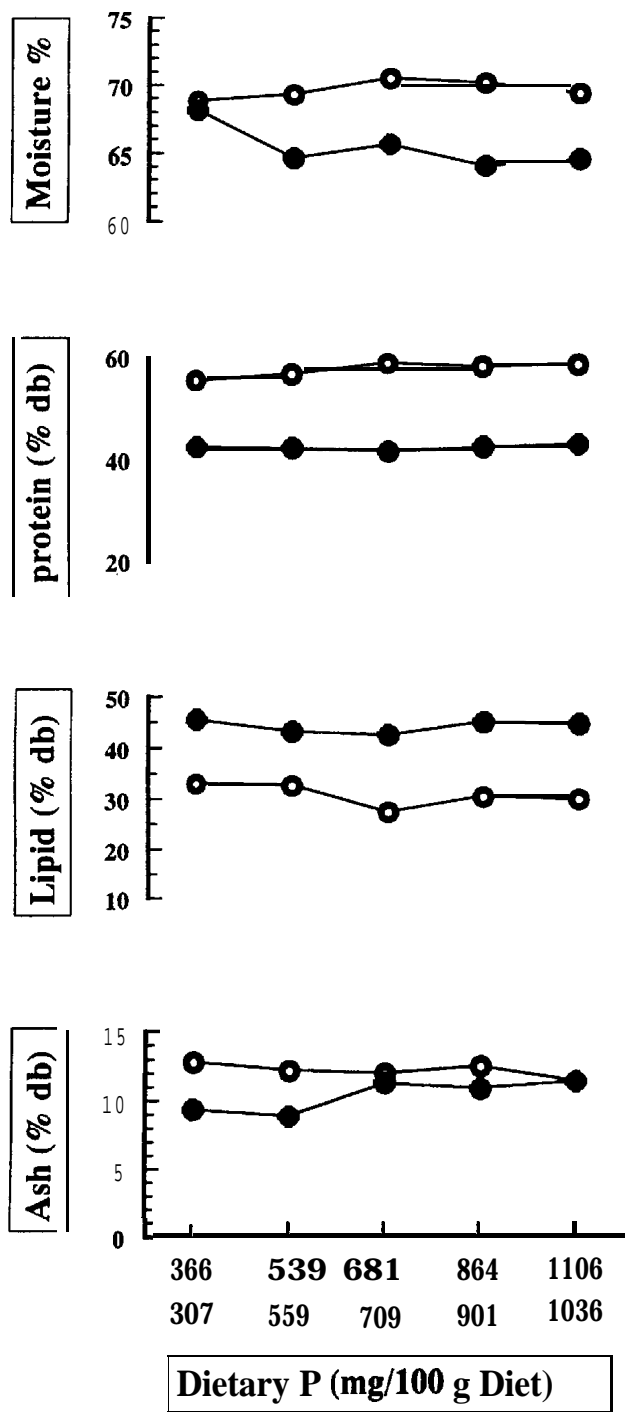

Fig. 5. Proximate composition of the liver of zero (open circle) and one year-old (solid circle) redlip mullet fed on diets containing graded levels of dietary phosphorus for 14 and 12 weeks, respectively. Dietary P of Exp. I (upper scale) \& Exp. II (Lower scale). 


\section{REFERENCES}

Andrews, J. W., T. Murai and C. Campbell 1973 Effects of Dietary Calcium and Phosphorus on Growth, Food Conversion, Bone Ash and Hematocrit Levels of Catfish. J.Nutr., 103: 766-771

Ichikawa and Oguri 1961 Metabolism of Radionuclides in Fish. I. Strontium- Calcium Discrimination in Gill Absorption. Bull.Jap. Soc.Sci.Fish., 27: 351

Ketola, H. G. and M. E. Richmond 1994 Requirement of Rainbow Trout for Dietary Phosphorus and Its Relationship to the Amount Discharged in Hatchery Effluents. Trans.Am.Fish.Soc., 123: 587-594

Lall. S. P. 1991 Digestibility, Metabolism and Excretion of Dietary Phosphorus in fish. In "Nutritional Strategies and Aquaculture Waste. Proceedings of the First International Strategies in Management of Aquaculture Waste (1990)“. ed. by C. B. Cowey and C. Y. Cho, Univ. of Guelph, Guelph, Ontario pp. $21-26$

Nose, T., and S. Arai 1979 Recent Advances in Studies on Mineral Nutrition of Fish in Japan. In "Advances in Aquaculture" ed. by T.V.R. Pillay and W. A. Dill, Fishing News Books, Farham, Uk. pp. 584-590

Ogino, C. and H. Takeda 1976 Mineral Requirements in Fish-III, Calcium and Phosphorus Requirements in Carp. Bull.Jap. Soc. Sci.Fish., 42: 793-799

Ogino, C. and H. Takeda 1978 Requirements of Rainbow Trout for Dietary Calcium and Phosphorus. Bull.Jap.Soc.Sci.Fish., 44: 1019-1022 ( In Japanese)

Ogino, C., L. Takeuchi, H. Takeda and T. Watanabe 1979 Availability of Dietary Phosphorus in Carp and Rainbow Trout. Bull.Jap.Soc. Sci. Fish., 45: 1527-1532 ( In Japanese)

Sakamoto, S. and Y. Yone 1978 Effect of Dietary Phosphorus Level on Chemical Composition of Red Sea Bream. Bull.Jap.Soc.Sci.Fish., 44: 227-229

Sakamoto, S. and Y. Yone 1980 A Principal Source of Deposited Lipid in Phosphorus Deficient Red Sea Bream. Bull.Jap.Soc. Sci. Fish., 46: 1227-1230

Tempeletone and Brown 1963 Accumulation of Calcium and Strontium by Brown Trout from Waters in the United King-dom. Nature, 198: 198

Wilson, R. P., E. H. Robinson, D. M. Gatlin III and W. E. Poe 1982 Dietary Phosphorus Requirement of Channel Catfish. I.Nutr., 112: 1197-1202

Wu, H. 1984 The Fishes of Fujian Pronince (ed. by Fishes of Fujian Province editorial subcommittee) Fujian Sci. Technol. Press, Fujian China, 1984, pp. 493-494

Yone, Y. and N. Toshima 1979 The Utilization of Phosphorus in Fish Meal by Carp and Black Sea Bream. Bull.Jap.Soc.Sci. Fish., 45: 753-756 